\title{
Implementation of Mind Mapping Learning Model to Improve Learning Outcomes of Civil Education Subject
}

\author{
Zain Ahmad Fauzi*, I Nyoman Sudjana Degeng, Sa'dun Akbar \\ Graduate Program of Elementary Education, Universitas Negeri Malang, Malang, Indonesia.
}

\begin{tabular}{|c|c|}
\hline ARTICLE INFO & A B S T R ACT \\
\hline \multirow[t]{2}{*}{$\begin{array}{l}\text { Received: 09-03-20I7 } \\
\text { Revised: 08-05-20I7 } \\
\text { Accepted: 07-06-20I7 } \\
\text { Keywords: } \\
\text { Mind, mapping, learning, } \\
\text { outcome, model }\end{array}$} & $\begin{array}{l}\text { This research is to describe the implementation of mind mapping learning model } \\
\text { that can improve the learning outcomes of civil education subject. This research was } \\
\text { conducted at Public Elementary School Mawar } 2 \text { of Banjarmasin, specifically on } \\
\text { grade } 5 \text { students involving } 29 \text { students consisting of I3 male students and I6 female } \\
\text { students. This research is classroom action research. The data analysis used was } \\
\text { descriptive quantitative. The research results show the learning outcome of students } \\
\text { on Civil Education subject is improving in every meeting. Therefore, mind mapping } \\
\text { learning model can improve learning outcome of students. }\end{array}$ \\
\hline & $\begin{array}{l}\text { (c) } 2018 \text { The Authors. Journal of K6, Education, and Management (j-K6EM). ISSN: } 2580-2135 . \\
\text { Published by Graduated Program of Educational Management, Universitas Lambung } \\
\text { Mangkurat, Banjarmasin, Indonesia. This is an open access article under the open journal } \\
\text { systems. }\end{array}$ \\
\hline
\end{tabular}

*Author correspondence: Zain Ahmad Fauzi; E-mail: zain.fau@gmail.com 



\section{Introduction}

Education is a conscious activity aimed at developing human capabilities (Djamarah, 2000). The purpose of education contained in Law Number 20 on national education system, especially in article 3 which is developing learners' potential so that they become persons imbued with human values who are faithful and pious to one and only God; who possess morals and noble character; who are healthy, knowledgeable, competent, creative, independent; and as citizens, are democratic and responsible. Generally, Education is divided into formal education and non-formal education. Formal education is performed continuously in every types and level of education on every educational unit.

Educational unit is an education service group that organizes education. School is one of educational institutions providing various learning activities. Learning is an activity in which student is the active learning subject who creates their own cognitive structures (Vygotsky, I978: I34). Students as one of the important parts in educational field requires special attention when giving treatment. Learning is not merely memorizing, identifying, and recalling (Arfiyanti, 2017). However, students are also required to understand the concept and explain it as well as describing their understanding through pictures (Cabahug, 2012). In addition, students are also required to manage the information to achieved learning outcome (Degeng, 2004). According to Akbar (2013) learning process should be able to encourage motivation and easier learning understanding for the learners.

From the observation results, it showed that the implementation of learning process in the field was still far from the expectation mentioned above. It led to poor learning outcome of students which was still below the expectation. Especially for Civil Education Subject that explains long and boring materials for the learners. The same thing also applied to Public Elementary School Mawar 2 of Banjarmasin. So, it needs a proper solution to improve learning outcome of the students especially for Civil Education subject. One of the proposed solutions is the implementation of learning model.
Learning model can be defined as a systematic procedure used to organize learning experience for the learners, so the learning objectives can be achieved. According to Joyce \& Weil, learning model is a plan or pattern used to organize curriculum (long term learning plan), design learning materials, and guide the learning in the classroom or others (Rusman, 2010). One of learning model that can be used to achieve learning outcome expected by Civil Education subject is mind mapping.

Mind mapping is representation of thought process written in the form of images with diagrams, colors, symbols, and words (Buzan, 2009). This learning model is considered able to improve students' learning outcome since it does not only require students to memorize the whole material, but it is conceptualized more systematically and structured. Buzan further explains that Mind mapping leads to left and right brain activity by evoking critical thinking that leads to the reflective and functional of human brain. 4 characteristics of mind mapping learning model are (I) the subject of attention is manifested in the image at the center which is the main theme; (2) the main theme is then divided into sub themes; (3) the branch contains keywords associated with the lines, and (4) branches are linked structurally. Many researches have implemented mind mapping model and showed significant improvement in the learning outcomes.

\section{Methodology}

This was classroom action research conducted in 3 cycles. Each cycle covers 4 stages of planning, implementation, observation, and reflection.

This research was conducted at Public Elementary School Mawar 2 of Banjarmasin. The subject of the research was all grade 5 students involving 29 students consisting of I3 male students and I6 female students.

The analysis used descriptive quantitative technique that was obtained from students learning outcome. Based on the observation conducted by the researcher, it showed that 5I.72\% (I5 Students) have not achieved KKM (Minimum Mastery Criteria) of Civil Education subject. The research was categorized as successful if students 
able to achieve mastery of learning outcome $\geq$ $80 \%$ with Minimum Mastery Criteria (KKM) $\geq$ 75 classically.

\section{Results and Discussion}

The research conducted for 3 cycles at Grade 5 Public Elementary School Mawar 2 of Banjarmasin indicated the learning outcome had improved in each cycle. In the first cycle, it did not show a significant improvement of learning outcomes. This is because the students felt inconvenient with learning that implements mind mapping model. In the second cycle, learners started to get used to the implementation of mind mapping model, it also showed good things on student learning outcome. In the third cycle, the improvement of learning outcome appeared significant.

After learning outcome data of students was analyzed, the researcher created table of the average learning outcome of Grade 5 students at Public Elementary School Mawar 2 of Banjarmasin as presented in line charts.

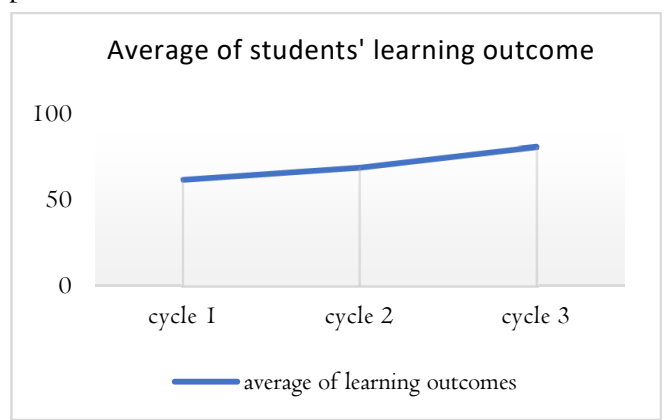

The picture above shows the improvement of students learning outcome average on Civil Education subject due to Mind Mapping model Implementation in the learning process.

In addition, the improvement also occurs on learning outcome of students classically, based on the scores obtained on the chart above, it shows improvement on the students learning outcome of Civil Education subject in each meeting. It was only $51.72 \%$ of students who were able to achieve Minimum Mastery Criteria at the beginning of the observation. It improved as many as $13.79 \%$ to $65.5 \mathrm{I} \%$ at first meeting and improved more at the second meeting, to $75.86 \%$ and improved more at the third meeting of $13.79 \%$ to $89.65 \%$.

In current education paradigm, the objectives of learning are not only studying the subjects' substance but refers more to the concept of constructivism that encourages and appreciates their learning efforts. With such active learning scenarios, students will strive to empower all their academic potential and strategies to solve individual/group problems (Djamarah, 2000).

\section{Conclussion and Recomendations}

Based on the results explanation and discussion above, it can be concluded that the implementation of mind mapping learning model on Civil Education subject at Public Elementary School Mawar 2 of Banjarmasin can significantly improve learning outcome of students.

Recommendations in the research is proposed to: (I) teacher is suggested to use mind mapping learning model when performing teaching and learning process, (2) the principal is encouraged to familiarize mind mapping learning model to teacher or other education implementer, (3) future researcher, it can be used as consideration and reference when conducting similar research.

\section{Acknowledgment}

No acknowledgment

\section{References}

Akbar, S. (20I3). Instrumen perangkat pembelajaran. Bandung: Remaja Rosdakarya.

Arfianti, D., Edy, B.I., \& Purwanto. (2017). Peningkatan pemahaman konsep himpunan melalui mind mapping kelas vii smp. Jurnal pendidikan: Teori, Penelitian dan Pengembangan. 2. 799-805.

Arsyad, A. (2013). Media pembelajaran. Depok:

Aslamiah \& Zain, A.F. (20I4). Meningkatkan hasil belajar siswa pada mata pelajaran pkn materi keputusan bersama melalui model mind mapping yang divariasi dengan role playing di kelas $\mathrm{v}$ sdn teluk tiram 2 banjarmasin. Jurnal Paradigma. 9(2). $37-40$.

Buzan, T. (2009). Buku pintar mind mapping. Jakarta: PT Gramedia.

Cabahug, J.A. (20I2). Concept mapping, mind mapping and argument mapping: what are the differences and do thehy matter? High educ. 62. 279-30I.

Degeng, I.N.S. (2004). Belajar dan Pembelajaran. Malang: Laboratorium Teknologi Pendidikan FIP UM. 
Djamarah, S.B. (2000). Guru dan anak didik dalam interaksi edukatif. Jakarta: Rineka Cipta.

Hidayat I., Siti, M.T., \& Ruminiati. (20I7). Penerapan model pembelajaran cooperative script berbantuan mind mapping untuk meningkatkan eterampilan berpikir kritis dan hasil belajar ips siswa kelas v. Jurnal Pendidikan: Teori, Penelitian, Dan Pengembangan. 2. 562-568.

Rusman. (20I0). Model-model pembelajaran mengambangkan profesional guru. Jakarta: Raja Grasindo Persada.

Viclara D., Mahardjito, Supriyono, K.H. (2016). Efektivitas mind mapping dan pengetahuan awal terhadap penguasaan konsep fisika siswa sma pada materi fluida. Jurnal Pendidikan: Teori, Penelitian, Dan Pengembangan. I. I0I-I05.

Vygotsky, L.S. (1978). Mind in society: the development of higher psychological Processes. Cambridge, MA: Harvard University Press. 
ISSN 2580-2135 